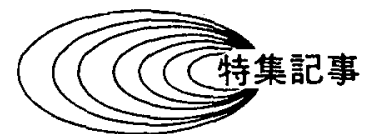

\title{
多色油膜法によるポンプ内部の流れの可視化 およびキャビテーションの可視化*
}

岡本 秀伸**，能見 基彦**，勝俣 辰善**

\section{Visualization of Pump Internal Flows using Multi-color Oil-film Technique and Visualization of Cavitation}

\author{
Hidenobu Okamoto, Motohiko Nohmi and Tatsuyoshi Katsumata
}

\section{1.まえがき}

ターボ機械の開発を行う場合，近年ではCFDを用い て内部流れの検討を行うことが多いが，CFDによる予 測の妥当性及び精度の検証をしておく事は非常に重要で ある。また，多相流に関しては，近年各種の市販 CFD コードで取り扱うことが出来るようになってきたが，現 状では予測精度の確認をしている段階で，実際の設計業 務に適応出来る段階までは至っていない．

流れの可視化によるターボ機械内部流れの把握は, CFDの信頼性の検証に用いるとともに，CFD が開発に 使用できない分野では，現象理解のための重要なッール となる.

本稿では, 当社で行われた様々な夕ーボ機械の可視化 の中から，多色油膜法による可視化とキャビテーション の可視化について紹介する。

\section{2. 多色油膜法によるポンプ内部の流れの可視化}

\section{1 多色油膜法}

本章では，当社で開発，使用さ机ている蛍光粉术を顔 料とする多色油膜法を紹介し, 適用事例として, 比速度 $280\left(\mathrm{~m}^{3} / \mathrm{min}, \mathrm{m}, \mathrm{min}^{-1}\right)$ のディフューザポンプの羽根 車及びディフューザの可視化結果を報告する．本手法は， 種々の 2 次流れが複雑に干渉し合う流動現象の把握に特 に有効であり，既に，ポンプの 3 次元 CFD 解析の検証 用に多く活用されている1)-3).

流路壁面上に油膜を塗布し，その流動パターンから流 れ場を診断する「油膜法」は, 流れの可視化技術の一つ として広く用いられてきた．油膜法によれば，はく離な どを含む複雑な流れの時間平均的なフローパターンを比 較的簡単に観察できることから，翼や物体周りの外部流 れ，あるいはターボ機械の内部流れへの適用事例が多く 報告されている゙．

油膜法は，通常の開発業務の一環としても比較的容易 に実施可能であり，また近年ターボ機械の設計開発ッー

* 原稿受付 2003 年 8 月 12 日

** 侏萑原総合研究所 機械研究室
ルとして定着したCFD 解析の信頼性を検証するための 流れ場の実験デー夕を蓄積する手段の一つとしても有望 である。

ポンプ流路内の異なる部位を，複数色の油膜で塗り分 けて可視化案験を実施すれば，異なる色の油膜が壁面せ 几断㐫力の作用で移動しあるいは混合して，中間色を含 む多色の油膜パターンが得られる。こうして得た油膜パ ターンの色調を観察することにより，流路内部の 2 次流 れの干渉状況や発生源を容易に把握することができる。

しかしながら，従来の油膜法で使用されていた酸化于 タン (白)，四三酸化鉛 (赤) 等の各種顔料は, 密度や 物性が互いに大きく異なるため，多色油膜法の顔料とし て採用しても，鮮明な中間色を得ることができず，色の 偏りを生じる。また，これらの顔料は密度が $4 \sim 9 \mathrm{~kg} / \ell$ と大きいので油膜と清水間の密度差の影響を受けやすく， 特に回転する羽根車内部の可視化には適さない。

上記の問題を解消するために，当社に扝いて，蛍光粉 末を顔料とする，新しい多色油膜法を開発した，蛍光粉 末としては, 緑色, 赤色, オレンジ色, 黄色, 桃色, 青 色など種々の色が市販されている。例えば， 3 原色(赤, 黄, 青) の蛍光粉末を油膜の顔料として用い, 羽根車の 負圧面・圧力面・ハブ面の各々を異なる色で塗り分けた 上で実験を行えば，2次流れなどによる流線の合流点で は，流動パターンに応じ緑やオレンジ，紫，紺といった 中間色を鮮明に得ることができる．従来の油膜法と比較 し，多色油膜法は下記の特徽を有している.

・蛍光を有する粉末を顔料に使用するので流線が鮮明

・顔料と油がなじみやすく相性が非常に良好

・色調により流れの方向，はく離，合流や 2 次流れの把 握が容易

・目的に応じ，顔料の色と種類を自由に選択できる

・顔料の色によらず平均粒径, 密度, 物性が同一

・顔料の平均粒径が約 $5 \mu \mathrm{m}$ と小さく均一なので流線が 緎細

・颜料の密度が約 $13 \mathrm{~kg} / \ell$ で油膜の密度が清水に近い ・密度が小さく静止流路の気流の可視化にも使用可能 多色油膜法の詳細と実施上の留意点については，文献 
に詳しく記述してあるので興味のある方は参照された い.

\section{2 可視化事例}

Fig. 1 に示すような, 比速度 $280\left(\mathrm{~m}^{3} / \mathrm{min}, \mathrm{m}, \mathrm{min}^{-1}\right)$ のディフューザポンプの, 設計点流量の $70 \%$ の部分流 量における可視化事例を紹介する。蛍光粉末としては, 3 原色（赤，黄，青）を用いた。羽根車，デュフューザ とも，ハブ面及びシュラウド面(あるいはケーシング面） を青色，羽根負圧面を黄色，羽根圧力面を赤色の油膜で 塗り分けた上で, 約 5 分間ポンプを運転したのち油膜パ ターンを観察・写真撮影した。

Fig. 2 に羽根車流れの可視化結果を示す. 供試羽根車 はクローズド羽根車で, 図の上段は, 羽根車にネジ止め されていた側板内壁面における油膜パターンを示す。

$70 \%$ 流量では, 羽根車入口逆流の初生により複雑な フローパターンを示している. Fig. 3 は, Fig. 2 のシュ ラウド壁面及び羽根負压面におけるフローパターンをス ケッチしたもので，異なる色を有する流線の領域と，対 応する 2 次流れの記号を示す. Fig. 3 には，シュラウド 上と羽根端面の対応する位置が記号 X で示してある. 入口逆流 $(\mathrm{I}, \mathrm{G})$ の発生により，シュラウド面上の流 路方向流れが消滅するため, 羽根間 2 次流れ F が流路 を横断して羽根負圧面上に流入する。この結果, 同領域 では羽根負圧面上の黄色の油膜流線の中に，シュラウド に塗布してあった青色の油膜が四方に飛び散ったように 現れている (2 次流れ C, D, E)。2 次流れ C, D, E の作用で，設計～過大流量では発達する羽根負圧面上の 子午面 2 次流れ B の発達が抑制されている.

Fig. 3(a)の領域 Gでは, 青色の流線の中に黄色の流

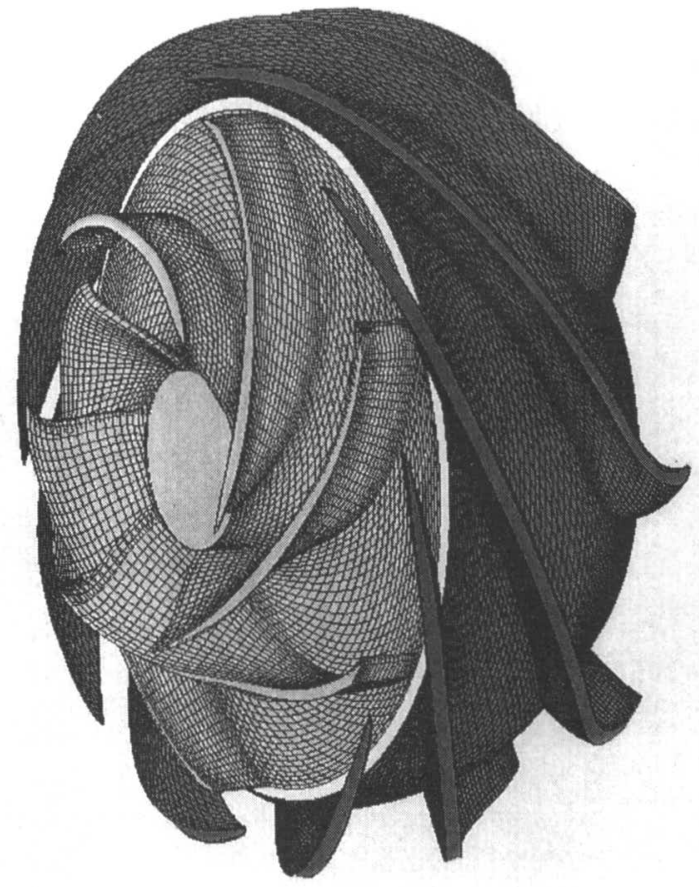

Fig. 1 Ns 280 diffuser pump. (Computational grid used in CFD)
線が混在している。これは，負圧面上の油膜が入口逆流 に巻き込まれてシュラウド面へ運ばれ生じたものと考え る. 羽根負圧面では, Fig. 3(b)に示すように, 流入流れ とシュラウド側からの 2 次流れ C, E，そして子午面 2 次流れ B どが互いに干涉し，境界流線 $\mathrm{B}_{0}$ と $\mathrm{E}_{0}$ など

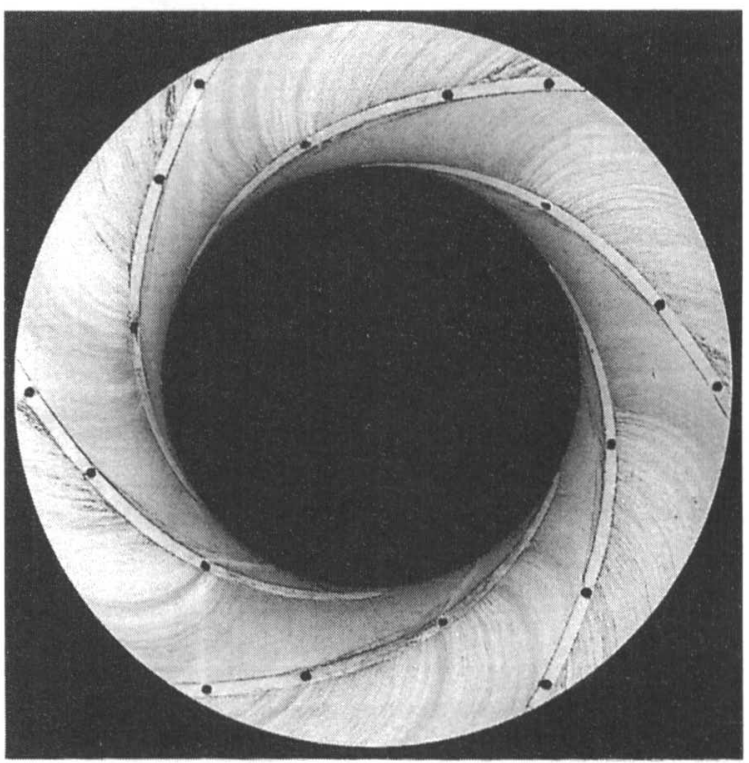

(a) Shroud surface

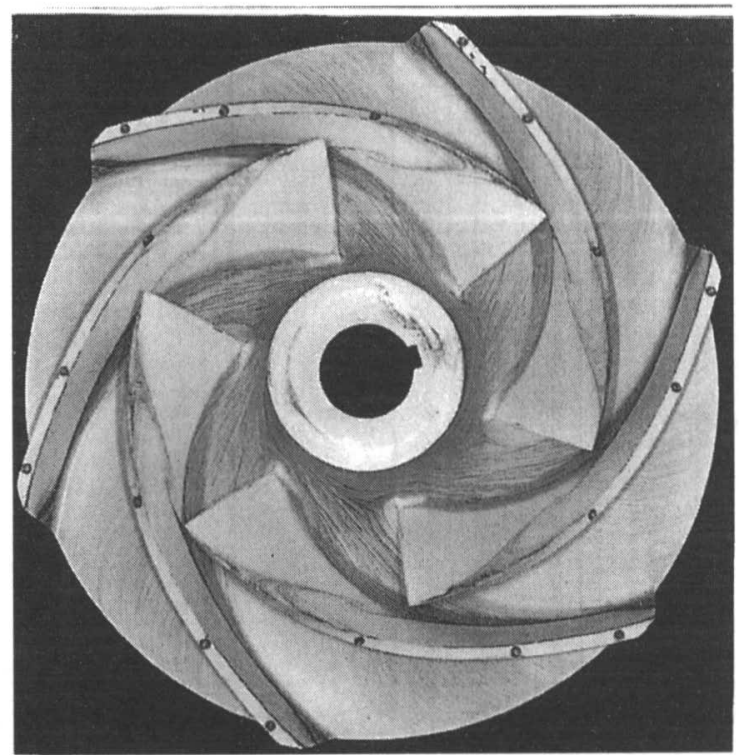

(b) Impeller front view

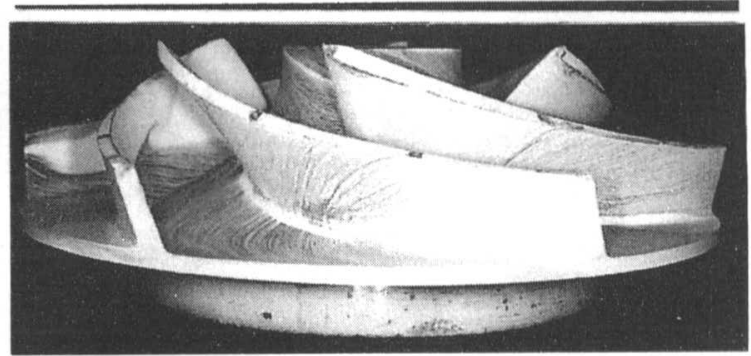

(c) Impeller side view

Fig. 2 Oil-film flow pattern of impeller at $70 \%$ flow rate. 


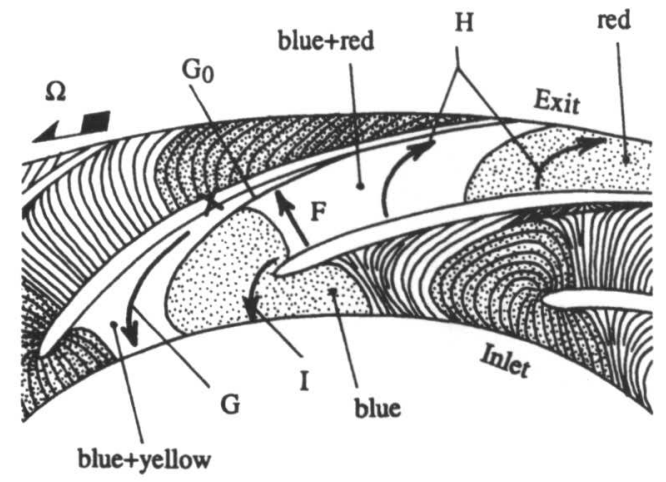

(a) Wall streamlines on shroud

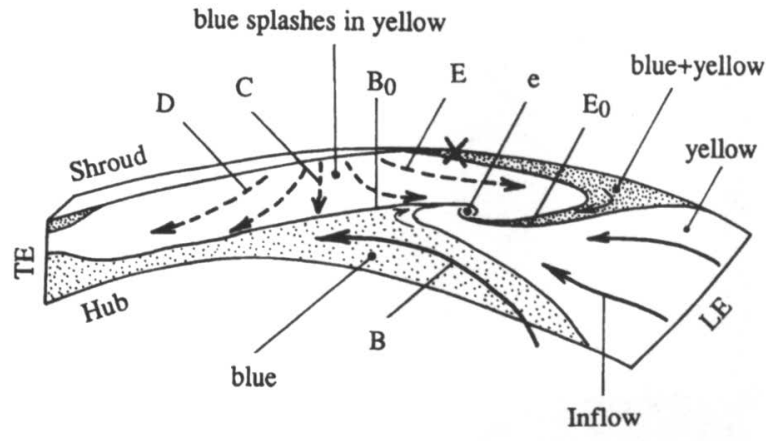

(b) Wall streamlines on blade suction surface

Fig. 3 Sketch of oil-film flow pattern of impeller at $70 \%$ flow rate.

が形成され，その合流点に渦 e が生じている．渦 e は, 正流域と逆流域との間のせん断流れ部の境界に生じる渦 糸の一端に対応すると考える. 渦糸の他端は, 入口逆流 の初生により, 羽根車上流へ向かって流出していると推 察できる. CFD 結果との比較については，文献を参照 されたい".

Fig. 4 にディフューザ流れの可視化結果を示す. 低比 速度ディフューザでは, 羽根車出口流れの旋回速度が早 いのと，ハブ面における子午面の局率が大きいため，特 にディフューザ外径をコンパクト化し高負荷化した場合 には，ハブ面上で大規模はく離が発生し易い。本事例に おいても，ディフューザ・ハブ面後半部の負圧面側には く離渦が発生している. 羽根の圧力面で発生する子午面 2 次流れ（赤色の流線）は, 羽根圧力面をケーシング側 からハブ側へと向かった後，流路後半部でハブ面へ流入 し，流路を横断して負圧面側へ向かい，はく離渦（顔料 が混ざって黒色になった領域）の中心に吸い寄せられて いく，一方, 羽根入口部では, 負圧面側上をハブ側へと 向かう子午面 2 次流れ（黄色の流線）が生じている. 八 ブ面へ流入した黄色の流線の一部は，流路前半部で上流 側へ向かって逆流している，八ブ面では，流入した 2 種 類の子午面 2 次流れによる境界線が明瞭に観察できる. はく離渦の上流では，青色の油膜が塗布したときと同じ 状況で存在しており, 流線も観察できないことから流れ がよどんだ状態にあると考えられる，なお，ディフュー

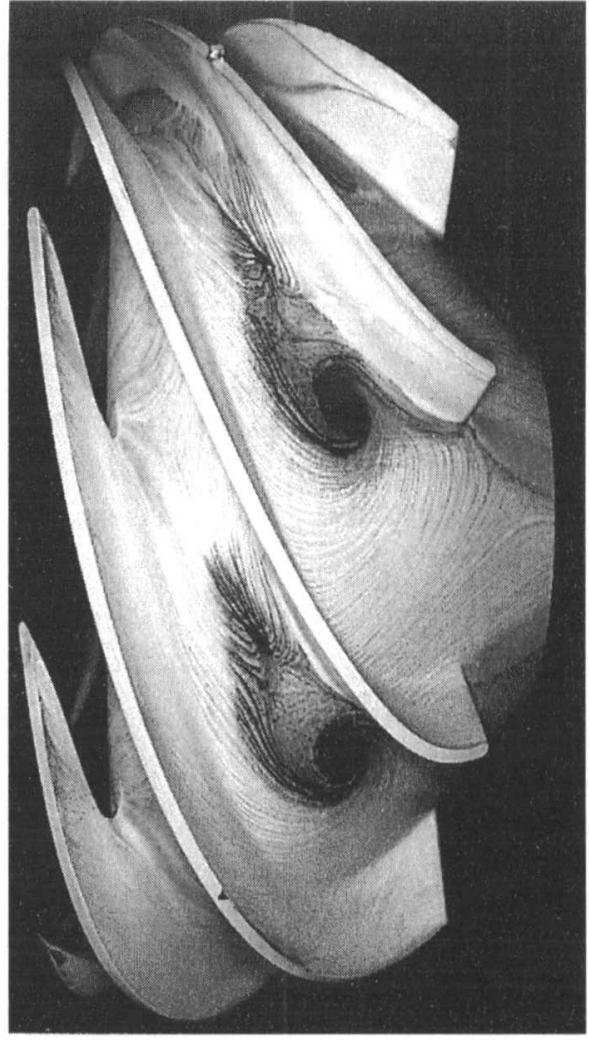

Fig. 4 Oil-film flow pattern of diffuser.

ザにおける CFD 結果との比較については，文献を参照 されたいり.

\section{3. 遠心ポンプキャビテーションの可視化}

本章では, 当社で行っている, ポンプ内に発生するキャ ビテーションの可視化事例（実験, CFD）について紹 介する.

\section{1 研究の背景}

1990 年代の前半に, 各企業においてターボ機械の設 計業務に圧縮性・非圧縮性 3 次元乱流 CFD が導入され 始めた。当時は単相流主体であり, 複雑な混相流の数値 解析を設計レベルで使用するのは困難であった．解析が 困難な混相流の代表選手の一つがキャビテーションであ る.キャビテーションは, 素過程と考えられる気泡の発 生消滅の時間空間スケールと, 設計者が扱う装置（ポン プや水車）の時間空間スケールが極端に異なり，さらに 相変化が含まれるため, 適切なモデル化を行わないと現 状のコンピュータの能力では解析が不可能である.この ような数值解析向けの各種のキャビテーションモデル化 が提唱されたのもおおよそ 1990 年代の前半と言える.

当社がターボ機械の単相流れ解析の次のチャレンジと して, キャビテーション解析の検討を開始したのは 1999 年であるが, 丁度この頃から様々な市販コードに各種の キャビテーションモデルが入り始め, その気になれば「今 日」にもキャビテーションが解析できる時代が到来して しまった. 企業の研究として, 複雑なモデル生成に手を 出さずッールとして利用に徹することができるのは有難 
い面もあるが，どの程度妥当な結果が出ているのか確認 が必要である。ポンプメーカではキャビテーションによ る揚程低下曲線の実験值を入手するのは容易であるが, このカーブだけで検証すると，結果が合わなかった場合 に立往生してしまう。市販コードの検証に広く用いられ ているのは Shen と Dimotakis の実験結果である ${ }^{6)}$. キャ ビテーショントンネル内の二次元翼型周りの静圧分布を 計測したものであるが，圧力面の测定孔が一つしかなく， 圧力面の静压分布の解析精度検証が困難である。近年で はDreißと Kosyna, Friedrichs と Kosyna が詳細な計 测を行っている7)-8). 彼らは，遠心ポンプの翼面にピエ ゾ抵抗効果を用いた圧力変換器を埋め迈み, キャビテー ション状態の翼面静压分布を計測している。筆者等は彼 らの実験装置を参考とし, キャビテーション流れ解析の 検証のために遠心ポンプ実験装置を製作してデータを取 得した。また，これを用いキャビテーション流れ解析の 検証も実施した。 以下に計測, 流れ解析における可視化 技法を中心に報告する。

\section{2 実験装置}

実験装置は，3枚の 2 次元翼を持つ比速度 $180\left(\mathrm{~m}^{3} /\right.$ $\left.\mathrm{min}, \mathrm{m}, \mathrm{min}^{-1}\right)$ の遠心ポンプである. 羽根車諸元を Table 1 に，ポプの断面構造図を Fig. 5 に示す.

キャビテーションは，空さえあれば見えるので可視化 の対象としては容易な部類かもしれないが，ポンプの場 合, 入口出口の配管類が光学系を邪魔すること, 羽根の 三次元的な曲がりがキャビテーションを部分的に鿵すこ と, 同じく三次元的な構造を持つキャビテーションでは 手前のキャビティが奥のキャビティを隠すことが可視化

Table 1 Design of Impeller.

\begin{tabular}{|c|c|}
\hline Impel ler Inlet Radius (mm) & 91 \\
\hline Impel ler Outlet Radius (mm) & 174 \\
\hline Span Width (mm) & 18 \\
\hline Inlet Blade Angle (deg) & 8 \\
\hline Out let Blade Angle (deg) & 10 \\
\hline Number of Blades & 3 \\
\hline
\end{tabular}

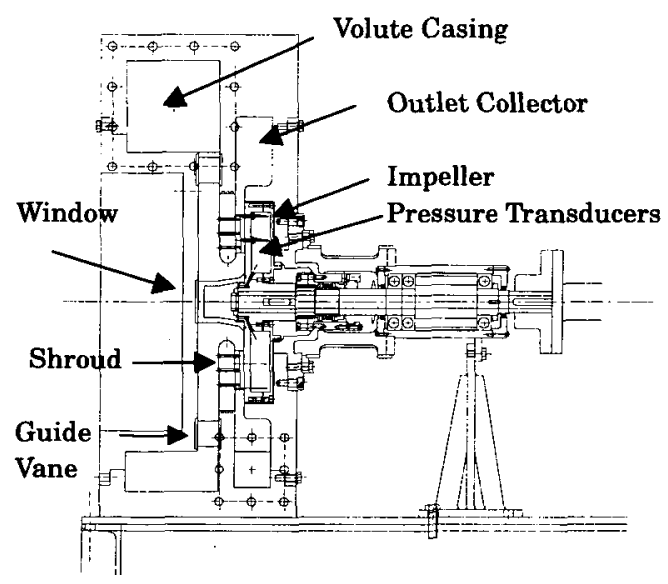

Fig. 5 Pump Cross Section.
計測を困難にする。そこで本装置ではポンプの入口形状 はボリュートに, 出口形状はコレクタにし, 通常の羽根 車上流で軸方向に伸びる入口配管を廃した。羽根車側板 と入口ボリュート壁面を全面アクリル平板とすることで， 羽根車前縁から後縁まで入口軸方向から容易に目視でき る構造である。また羽根も2 次元翼を採用することで 3 次元的なキャビテーションの生成を抑制し，流路の奥ま で見通せるようにした。このような空の棈造は Kleinert, Will, Finzelのドレスデン工科大学グループの 1979 年 の先駆的研究で用いられている この文献はドレスデン工科大学の東ドイツ時代の研究論 文で，装置の詳細構造が述べられておらず，ポンプ全体 の構造が不明のままだった. 本年 7 月の ASME-JSME 流体部門講演会において, 筆者の一人（能見）は偶然ド レスデン工科大学の研究者と出会い, Will 氏が教授とし て顕在なことがわかった．現在，当時の装置について問 い合わせ中であり，詳細が判明したらまたの機会にご報 告したい.

本実験装置において，ポンプ流路内のキャビテーショ ンはハイスピードビデオ (PHOTORON ultima RGB 3) とディジタルスチルカメラで撮影する. PHOTORON ultima RGB 3 は $256 \times 256$ のピクセルを有し, 撮像デー 夕をメモリーに記録する。本実験では毎秒 4500 コマで 撮影した。羽根にはKosyna らの装置を参考とし，18 個の小型絶対圧力変換器が主板側から挿入されシリコン オイルを封入した入口径 $0.5 \mathrm{~mm}$ の受圧孔を介して死力 面 8 点, 負圧面 10 点の非定常圧を同時計測する。受圧 孔の共振周波数は $2.5 \mathrm{kHz}$ であり，0.5 kHz まで線形な 圧力信号が得られる．圧力信号は，主板内のアンプを介 し，スリップリングを経て静止系に導かれる。

供試ポンプは，ブースターポンプ，流量調節用バルブ， タンク，電磁流量計を有する閉流路に取り付けられる。 実験時にはタンクに接続された真空ポンプを動作させ, ポンプ入口の NPSH ava.を変えてキャビテーションを 発生させる。その他，実験の詳細に関しては，文献を参 照されたい101。

\section{3 キャビテーション流れ解析}

本研究においては, 沉用流れ解析コードCFXTASCflow のキャビテーションモデル，および沉用市販 コード STAR-CD に当社と東北大学・井小萩教授との 共同研究で開発したキャビテーションモデルを組み込ん だものを用いた。CFX-TASCflow では Constant Enthalpy Vaporization (CEV) モデルが採用されてい る、本モデルでは，流線に沿って水一水蒸気の混合媒体 のエンタルピーが一定の条件で相変化が生じ, 水相と水 蒸気相は滑り無しに流動すると仮定する．解析では乱流

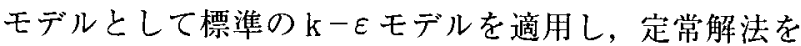
用いた。

東北大学との共同研究では, 計算格子内に存在する有 限個の気泡を無数の無限に微細な気泡粒子に近似し, 密 
度一圧力の一価関数を仮定する, いわゆるバロトロピー 流体のモデル化（通称 TE モデル）を行っている．キャ ビテーション気泡は水蒸気と微量な空気の混合気体から なると考え，下記の状態方程式を導出する ${ }^{11}$.

$\rho=\frac{\left(p+p_{c}\right)\left(p-p_{v}\right)}{(1-Y)\left(p-p_{v}\right) K\left(T+T_{0}\right)-Y \rho_{v} K\left(T+T_{0}\right) R a T+Y\left(p+p_{c}\right) R_{a} T}$

$$
\alpha=1-\frac{\rho}{\rho_{w}}\left(1-Y-\frac{\rho_{v}}{\rho_{a}} Y\right)=\frac{Y \rho}{\rho_{a}}=\frac{\rho_{w}-\rho}{\rho_{w}-\rho_{a}-\rho_{v}}
$$

ここで, $p$ は圧力, $\rho$ は密度, $T$ は温度, $R$ は気体定数, 添え字の $w, a, v$ はそれぞれ水 (液相), 空気, 水蒸気, $p_{c}, K, T_{0}$ は水単相に成立する Tamman 型状態方程式 の定数である. $\alpha$ は均質媒体中の気体の体積分率（ボイ ド率)， $Y$ は空気の質量分率 (一定值) である.この状 態方程式を用い, キャビテーション流れ場を圧縮性流体 とみなして解析した。乱流モデルとして標準の $\mathrm{k}-\varepsilon モ$ デルを適用し，定常解法を用いた。

\section{4 実験結果と解析結果}

本実験装置の最高効率点流量である $Q=0.95 \mathrm{~m}^{3} / \mathrm{min}$ および大流量 $1.25 \mathrm{~m}^{3} / \mathrm{min}$ の吸い込み性能曲線の実験 值と計算值を Fig. 6 に示す. Fig. 6 より $Q=0.95 \mathrm{~m}^{3} / \mathrm{min}$ に関しては，揚程低下点に関し TEモデルではやや NPSH が大きく, CFX-TASCflow ではややNPSH が小 さいが，ほぼ妥当に予測されていることがわかる，Q= $1.25 \mathrm{~m}^{3} / \mathrm{min}$ の場合, TE モデルの解析ではキャビティ 内の密度が低下しすぎ計算が不安定となった。一方, CFX-TASCflow では解析は実施できたが, 全揚程が漸 減する傾向が再現できず，いずれの解析でもモデル， ス キームの検討が必要であることが判明した.

Fig. 7 は $Q=0.95 \mathrm{~m}^{3} / \min に$ におるキャビテーション の発達状況である. Fig.7(a)，（b)はそれぞれ揚程低下 が $3.1 \% ， 36 \%$ である. $Q=0.95 \mathrm{~m}^{3} / \mathrm{min}$ では羽根車に ほほ無衝突で流れが流入し，キャビテーションは負圧面 の中程に初生する (Fig.7(a)). ポンプ入口圧力を低下 させるとキャビティが下流に伸張しスロートに達すると， 反対側の圧力面前縁付近からもくさび状のキャビティが 発生し, 揚程が急低下する(Fig. 7(b)). CFX-TASCflow

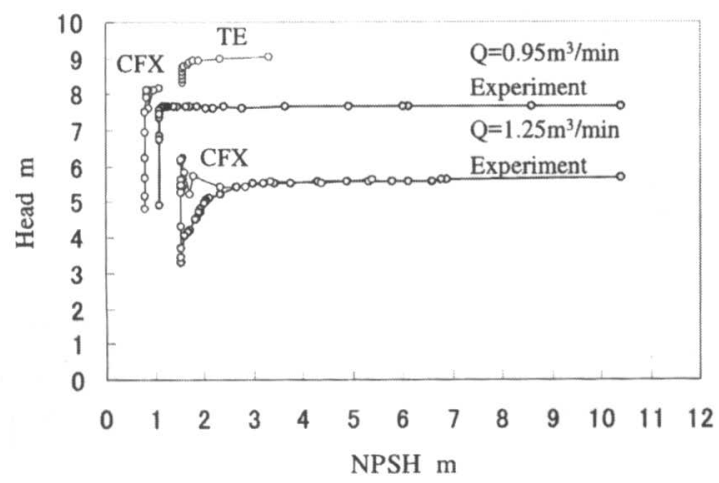

Fig. 6 Measured and Computed Suction Performance Curves.
の解析において, 揚程が完全に低下した状態のキャビ テーションの発生状況を翼スパン中央断面の等ボイド表 示で示したものが Fig. 8 であり, Fig. 7(b) と良く似た傾 向を示している. 一方, TE-モデル解析において, 揚程 が完全に低下した状態のキャビテーションの発生状況を 30\%の等ボイド率面で示したものが Fig. 9 である.

Fig. 9 において羽根前縁のやや上流で流路の中程, チッ プ側に低ボイド率の領域が生じている。これは側板の子 午面上での曲がりの影響，および翼列によって誘起され る翼上流の圧力場の相互作用により生じる低圧部に対応 する.このような領域での気泡は実験でも観察されてい るが, Fig. 9のものは実験結果よりも規模が大きく見える.

Fig. 10 (a)には実測された $Q=0.95 \mathrm{~m}^{3} / \min$ のキャビ テーション時の時間平均翼面圧力分布を, Fig. 10(b)に は CFX-TASCflow による揚程低下時の翼面圧力分布の 解析結果を示す. Fig. 10 (a) より，NPSHを低下させる と圧力面側の分布は前縁側から凹んでいき, 負圧面側の 分布は後縁側から平坦になっていく.この傾向は CFXTASCflowの結果で再現されている.

本実験では翼面圧力分布を非定常に同時計測しており,

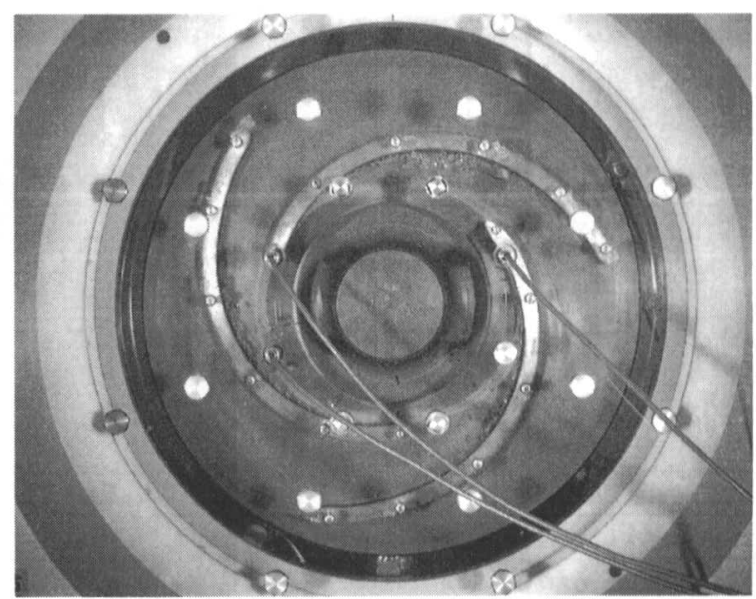

(a) Cavitation at Head Drop of $3.1 \%(\mathrm{NPSH}=1.081 \mathrm{~m})$

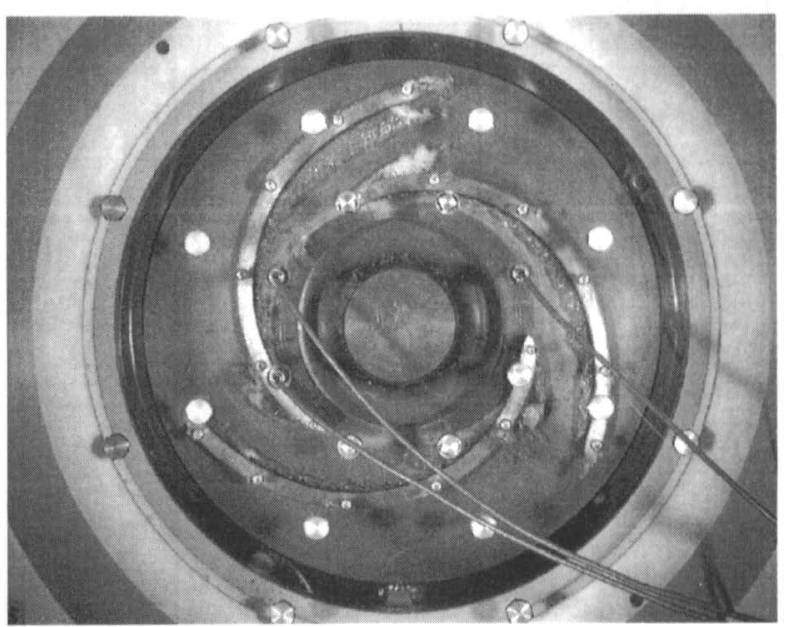

(b) Cavitation at Head Drop of $36 \%$ (NPSH=1.075 m)

Fig. 7 Cavitation Photographs at Head Drop. $\left(Q=0.95 \mathrm{~m}^{3} / \mathrm{min}\right)$ 


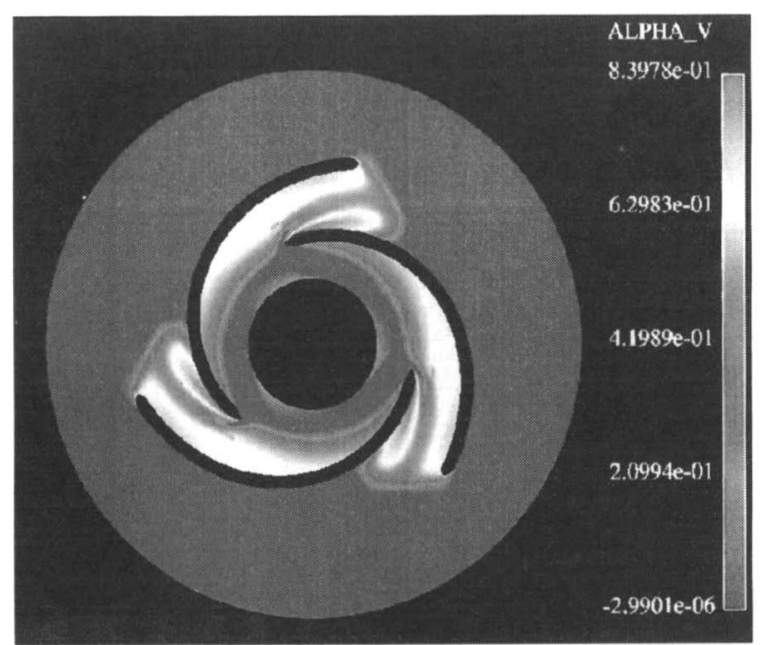

Fig. 8 Computed Void Fraction Contour at Head Drop. (CFX-TASCflow)

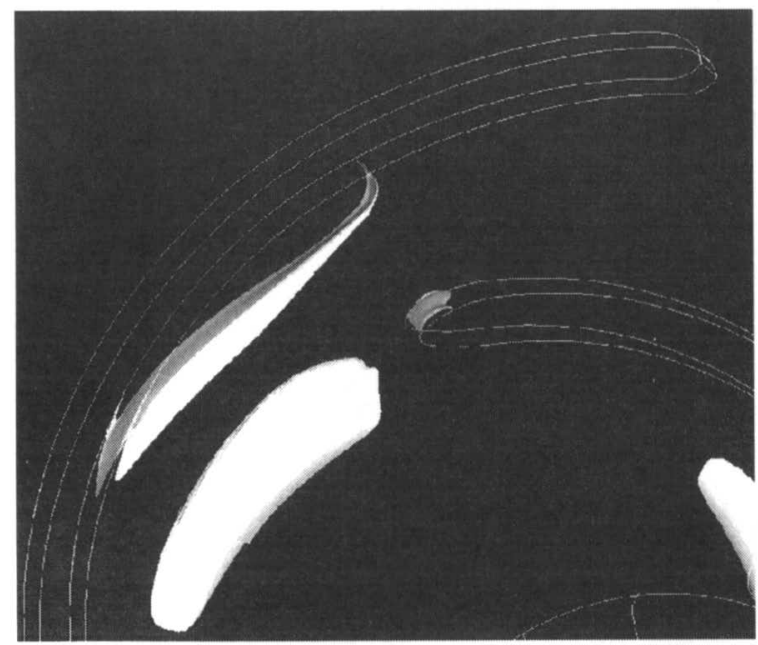

Fig. 9 Isosurface of Void Fraction $\alpha=30 \%$. (TE model)

圧力分布の動的な変化を動画として可視化することが可 能である.これを観察すると非キャビテーション状態, キャビテーション状態のいずれにおいても圧力分布が変 動することが見て取れる．同様の評価は各圧力点の波形 をFFT 解析することでも可能であるが, 動画像では各 圧力点間の関連も容易に把握でき示唆に富む.またハイ スピードビデオ撮影と圧力分布計測を同期して行ってお り，両者の動的な相関を観察することが可能である.

Fig. 11 には大流量 $Q=1.25 \mathrm{~m}^{3} / \mathrm{min}$ に扔いて揚程が $41 \%$ 低下した状態のキャビテーションの状況を示す. この流量ではキャビティが圧力面の前縁付近に初生し, これが成長することによって全揚程が漸隇する (Fig. 6).

\section{5 キャビテーション可視化の課題}

上述のように詳細計測結果との比較から，キャビテー ション流れ解析は完全ではないが, 設計ッールとしての 実用化に着実に近づいている印象を受ける。ここであら ためてキャビテーションの実験・流れ解析に残された課 題を整理すると下記のようになるのではないだろうか? (1)工学的・工業的に見た定常解析の評価（適したモデリ

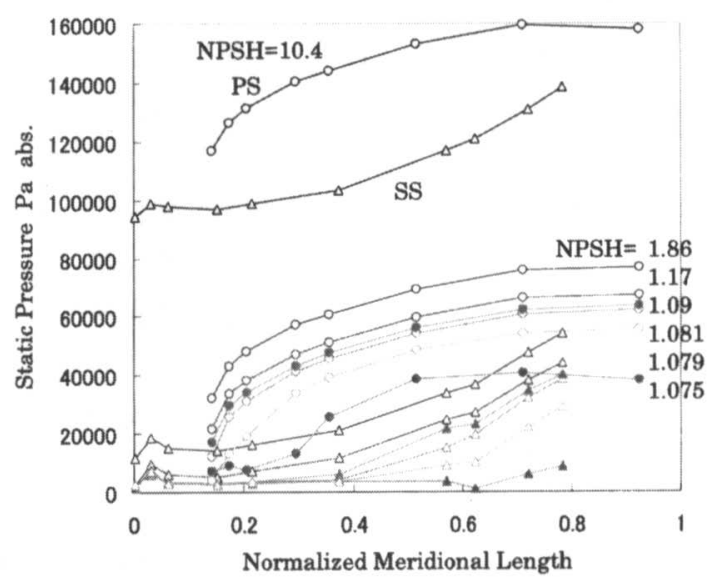

(a) Experiments

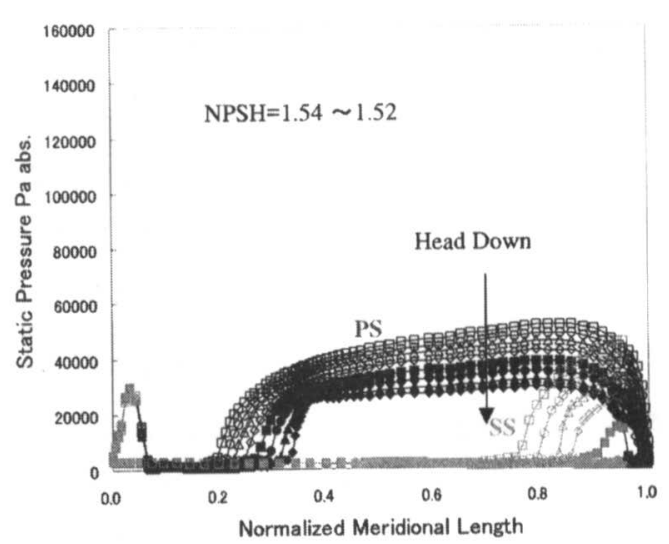

(b) CFX-TASCflow

Fig. 10 Blade Pressure Distribution at Head Drop.

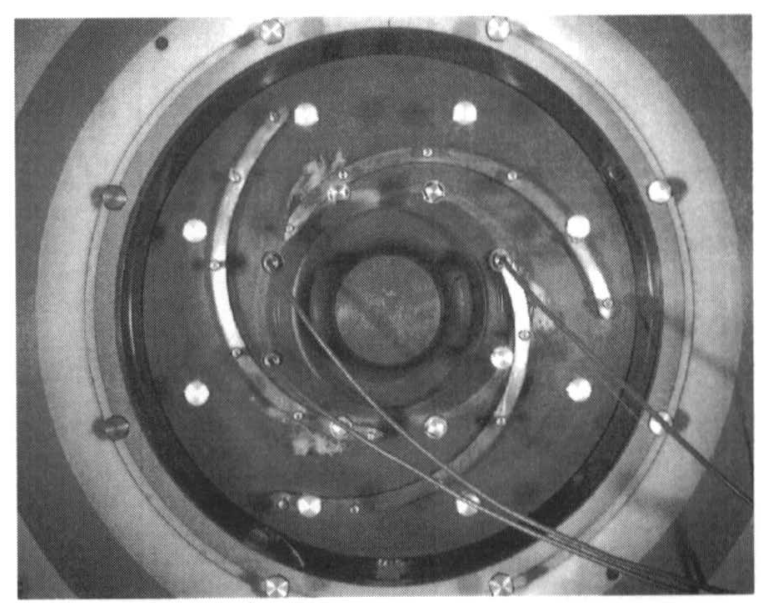

Fig. 11 Cavitation Photographs at Head Drop of $41 \%$. $\left(Q=1.25 \mathrm{~m}^{3} / \mathrm{min}\right)$

ングの開発）(2)旋回キャビテーション，サージ等不安 定現象への適用と検証 (3)二相流れ場解析結果の検証 (圧力や揚程ではない物理量, 例えばボイド率による検 証）(4)計算結果の評価方法の確立（二相状態の理論揚 程，全揚程をいかに定義するか？）(5)計算結果の可視 化評価方法の確立（キャビテーション写真と等ボイド率 コンターの相関) (6)水の基礎研究（キャビテーション 
核, 溶存気体，引張応力，音速，压縮性等に関する詳細 な計測と理論研究）(7)流体機械キャビテーション相似 則の再確認（オーバーオール值のみならずキャビテー ション流れ場の相似性の検討)

この内, 可視化と関連が特に深いのは(3)と(5)である. 流れ解析では二相状態をボイド率という連続量で扱うが これを何らかの形で計測し，計算結果と直接比較する必 要がある. 既存のボイド率測定技術, 例えばCT 法の適 用も有効であろう ${ }^{121.13)}$. ボイド率の直接計測ではないが ステレオ画像法とCT 法を組み合わせ翼面上のキャビ ティの 3 次元形状デー夕を取得する方法も今後有望に思 われる ${ }^{14}$. 一方, 解析結果からキャビテーションを可視 化するにはボイド率をコンターで表示するか (Fig. 8) 等 值面で表示する（Fig.9）のが一般的である。しかしな がら，これらの表示は選択するボイド率の值で大きく変 化し，場合によっては如何様にも実験結果と近づけられ る.この問題の解決にはボイド率が分布する空間におけ る光の伝播を解析し「見えるであろう」画像を生成する のが望ましい。このためには CGのレンダリング技術で あるレイトレーシング法やレディオシティ法等を用いて 生成したリアリスティックなキャビテーション画像と実 際のキャビテーション写真との相関づけを行う研究が必 要である。また(1)から(7)の全般にわたり，より高速・高 解像度のビデオカメラの適用が不可欠なのは言うまでも 無い.

\section{6 謝辞}

本研究遂行にあたり, 多大なご指導を頂いた東北大学 流体科学研究所 - 井小萩利明教授, 伊賀由佳博士に深甚 なる謝意を表します。

\section{4. まとめ}

本稿では, 多色油膜法による可視化とキャビテーショ ンの可視化について紹介した. 多色油膜法に関しては, その特徴とポンプへの適用事例について述べ，その有用 性を明らかにした。また，キャビテーションの可視化で は，高速ビデオカメラを用いた可視化の他 CFDによる 可視化例も示したまた，キャビテーションの可視化の 課題についても述べた。

\section{参考文献}

1 ) 後藤, 勝俣：機諭 B 61 - 591 (1995)pp. 3884

2) Goto, A.: Proceedings of Pump Congress. C 2-3., Karlsruhe (1996)

3) Goto. A.: FEDSM 97-3340(1997)

4）可視化情報学会編，「流れの可視化ハンドブック」，朝倉書 店, 1986

5 ）後藤，勝俣：多色油膜法によるポンプ内部流れの可視化，工 バラ時報，第 184 号 (1999) pp. 3

6) Shen, Y. T. Dimotakis, P. E., Proc. 22nd ATTC, St. Johns (1989) pp. 4

7) Drei B, A. Kosyna, G., JSME Centennial. Grand Cong. Fluid Eng. (1997) pp. 231

8) Friedrichs, J., Kosyna, G. Trans. ASME, J. Fluids Eng., Vol. 124 (2002) pp. 356

9) Kleinert. H.et al., Proc. 6th Conf. Fluid Machinery (1979) pp. 575

10) Nohmi et al., Proc. FEDSM '03, FEDSM 2003- 45409 (2003)

11）能見, 後藤, 伊賀, 井小萩：遠心ポンプのキャビテーション 流れ解析, 2003 年日本機械学会流体工学部門講演会投稿中

12) Adam M.S. et al. J. Hydraulic Research, Vol, 36 No. 4 (1998) pp. $707-719$

13）釸村,奥村，日本機械学会第 76 期全国大会講演論文集 III (1998) pp. $215-216$

14) Pereira F. et al, Trans. ASME J. Fluids Eng. Vol. 120 (1998) pp. $719-727$ 

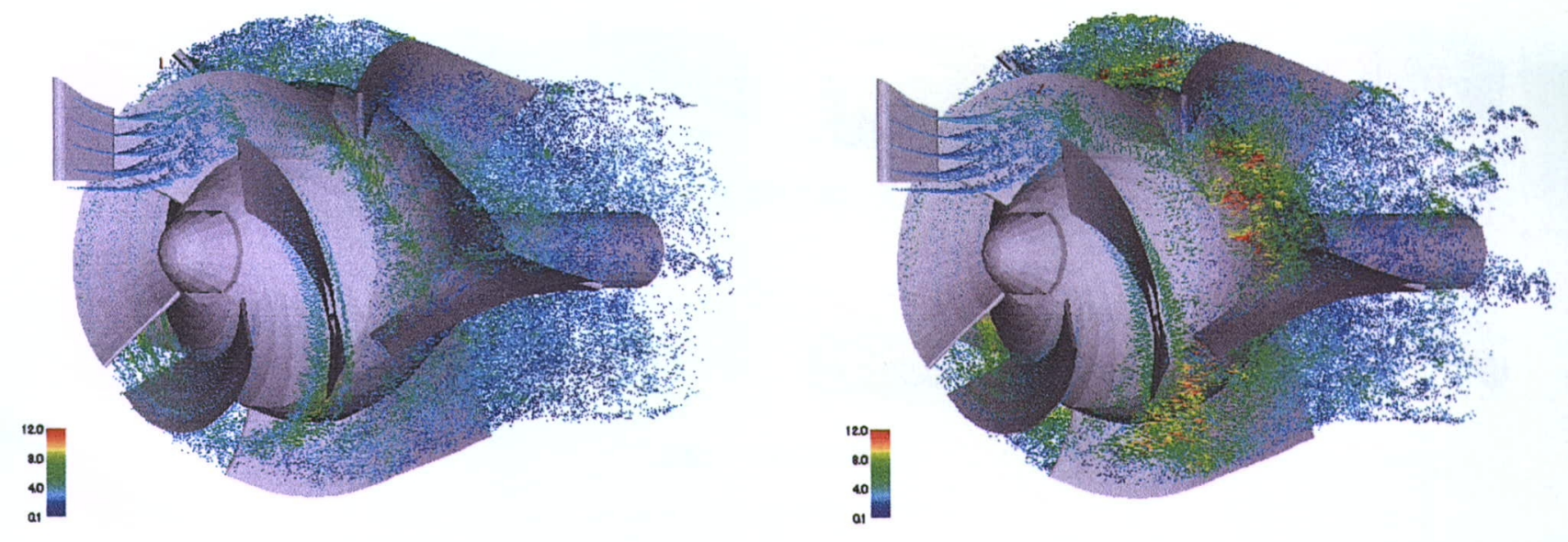

ロ絵 2 渦法による斜流ポンプ内の流れの可視化

(口絵 2 (侏)カレッジ・マスターハンズ 小島 成) (本文 199 頁参照)

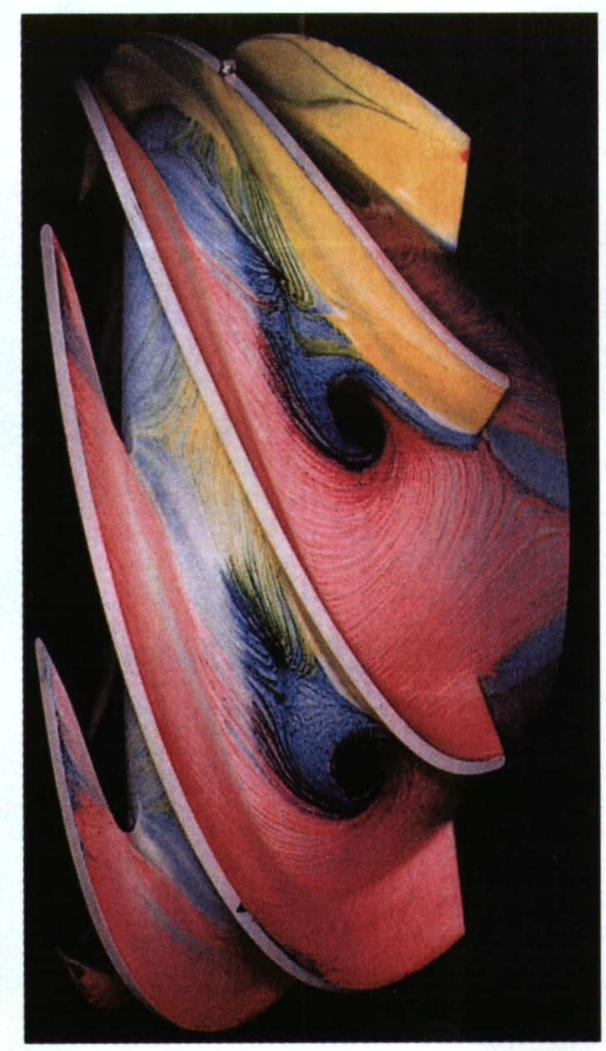

口絵 3 多色油膜法によるディフューザの油膜パターン (Ns 280)

(口絵 3 (㧣萑原総合研究所 岡本秀伸) (本文 220 頁参照) 